\title{
Grazing Impacts in Vegetated Dune Fields: Predictions From Spatial Pattern Analysis
}

\author{
Paula D. Blanco, ${ }^{1}$ César M. Rostagno, ${ }^{2}$ Héctor F. del Valle, ${ }^{2}$ Ana M. Beeskow, ${ }^{2}$ and Thorsten Wiegand ${ }^{3}$ \\ Authors are ${ }^{1}$ Research Fellow and ${ }^{2}$ Research Scientists, Unit Terrestrial Ecology, National Patagonic Center-National Council of Scientific and \\ Technological Research, Blvd Brown s/n, U9120ACV, Puerto Madryn, Chubut, Argentina; and ${ }^{3}$ Senior Scientist, UFZ Helmholtz Centre for \\ Environmental Research-UFZ Department of Ecological Modelling, Permoserstrasse 15, 04318, Leipzig, Germany.
}

\begin{abstract}
This study deals with the changes induced by grazing on soil erosion processes in vegetated dune fields of Península Valdés, in the Patagonia region of Argentina. We performed a spatial analysis to assess erosion features' patterns. Blowouts, used as main indicators of aeolian erosion processes, as well as dune crests, which are susceptible to erosion, were mapped on aerial photographs and images from Landsat 7 Enhanced Thematic Mapper Plus, in eight paddocks under two grazing conditions: lightly (0.4 sheep $\left.\cdot \mathrm{ha}^{-1}\right)$ and heavily grazed $\left(0.8\right.$ sheep $\left.\cdot \mathrm{ha}^{-1}\right)$. From the mapped locations of water points, crests, and blowouts we calculated a spatial statistic (O-ring statistic), which gives the expected intensity of blowouts within the area covered by crests as function of distance away from water points. Additionally, to explore if the density of crests around water points influences the density of blowouts, we estimated the intensity of dune crests in the neighborhood of water points and compared the densities of blowouts among water points with low, medium, and high densities of crests. For the heavy grazing treatment we found highly significant $(P<0.05)$ aggregation of blowouts around water points with peak densities threefold higher than expected at random occurring between 90 and $210 \mathrm{~m}$. However, the aggregation was only weakly significant for the light grazing treatment and occurred only at distances of about $30 \mathrm{~m}$ away from the water point. We found that the impact of grazing on soil stability contrasted among sites with different sensitivity to accelerated erosion. In sites with a high density of dune crests close to water points, wind erosion becomes more intense and the density of blowouts increases. A more sustainable management of these rangelands depends primarily on the conservation of the soils. Therefore, the location of water points in sites not susceptible to accelerated soil erosion would represent a better management strategy of the dune fields of Península Valdés.
\end{abstract}

\section{Resumen}

Mediante un análisis de patrones espaciales se evaluaron los cambios inducidos por el pastoreo ovino sobre procesos de erosión de suelos, en los campos de dunas estabilizadas de Península Valdés, Patagonia Argentina. Los hoyos de deflación, utilizados como principal indicador de procesos de erosión, al igual que las crestas de dunas, las cuales son altamente susceptibles a erosión, fueron identificados y digitalizados sobre fotografías aéreas e imágenes Landsat, en ocho potreros bajo dos condiciones de pastoreo: carga baja $\left(0.4\right.$ ovejas $\left.\cdot \mathrm{ha}^{-1}\right)$ y carga alta $\left(0.8\right.$ ovejas $\left.\cdot \mathrm{ha}^{-1}\right)$. Se calculó la densidad de hoyos en función de la distancia a la aguada por medio de un estadístico espacial (O-ring statistic), el cual fue contrastado con un modelo nulo donde los hoyos fueron aleatoriamente distribuidos sobre el espacio ocupado por las crestas. Para explorar si la densidad de crestas alrededor de aguadas influenciaba la densidad de hoyos de deflación, se comparó la densidad de hoyos entre aguadas con baja, media y alta densidad de crestas. El pastoreo afecta el patrón espacial de hoyos alrededor de las aguadas $(P<0.05)$, siendo este efecto más evidente en potreros con cargas altas. El patrón agregado de hoyos de deflación fue más fuerte y a mayores distancias de las aguadas con cargas altas (con picos de densidad de hoyos entre $90 \mathrm{~m}$ y $210 \mathrm{~m}$ ), que con cargas bajas (con máxima densidad de hoyos aproximadamente a $30 \mathrm{~m}$ ). En aquellos sitios con alta densidad de crestas alrededor de las aguadas, el impacto del pastoreo sobre el pastizal fue más intenso. Un manejo sustentable de estos pastizales depende prioritariamente de la conservación de los suelos. Por lo tanto, la localización de aguadas en sitios menos susceptibles a la erosión eólica representaría una mejor estrategia de manejo de los campos de dunas estabilizadas de Península Valdés.

Key Words: blowouts, Patagonia, ring statistic, soil erosion, spatial analysis

\section{INTRODUCTION}

Arid and semiarid ecosystems compose over one-third of the land surface of the world (OIES 1991). Among these, vegetated dune fields are systems that are extremely fragile and sensitive to disturbances because of high susceptibility to erosion of

Research was funded by Agencia Nacional de Promoción Científica y Tecnológica, Project PIP 02127, CONICET, Argentina.

Correspondence: Paula D. Blanco, Centro Nacional Patagónico, Puerto Madryn, Chubut, Argentina, U9120ACV. Email: blanco@cenpat.edu.ar

Manuscript received 28 April 2006; manuscript accepted 19 December 2007 sandy soils (UNEP 2006). Vegetation protects the surface via direct cover of the surface, trapping of particles, and most importantly by extracting momentum from the air flow (Wolfe and Nickling 1993). Vegetation cover varies with position on the dune-flanks are normally better vegetated than crests owing to soil moisture distributions and degree of exposure to wind events (Wiggs et al. 1995). There is also significant shortterm variation in dune system dynamics because of high interannual rainfall variability, droughts, localized fire, and human impacts such as livestock grazing (Wasson and Nanninga 1986). These factors can reduce vegetation cover leading to aeolian (wind-borne) sediment mobilization (Living- 
stone and Thomas 1993). A large number of dune systems both mesic and xeric also support biological soil crusts, which are easily compacted by trampling (e.g., Van den Ancker et al. 1985).

Livestock grazing can generate and accelerate soil erosion processes through intensive utilization of the rangeland (Pickup et al. 1994). Intensive grazing can be conditioned, among other factors, by the distribution of water points. In large grazed paddocks, with a single water point located at one corner, a direct trend predominates when gradients of several paddocks are pooled in a regional estimate: higher grazing pressure around water points, diminishing at increasing distance from it (Bastin et al. 1993). Lange (1969) coined the term piosphere for these utilization gradients.

Grazing impact is greatest close to a watering point and decreases with distance from the water for two reasons: 1 ) the area available to graze increases with distance from the focal point resulting in a reduction in density of stock and 2) stock have to drink regularly so they are limited in how far they can travel from water (James et al. 1999). As well as grazing effects, there are also effects from trampling associated with the movement of animals close to the watering point (Andrew and Lange 1986). Trampling is most obvious within a few hundred meters of the watering point, an area often called the 'sacrifice zone' (Valentine 1947).

Deterioration of arid rangelands caused by livestock can often be reverted by applying suitable methods of ecosystem management. However, traditional field-based studies on dryland ecosystems are usually confined to restricted areas or small samples, such as transects, suites of quadrats, and insideoutside-enclosure comparisons (Sparrow et al. 2003). Therefore, knowledge about the grazing process at the wholepaddock scale comes by extrapolation, sometimes supported by modeling, without considering that patterns and processes acting at broader scales may not be recognized when extrapolating from small to large areas (Ludwig et al. 2000). A different approach to studying effects of grazing on arid landscapes is achieved with spatial pattern analysis techniques that have been widely adopted recently (Ripley 1981; Haase 1995; Barot et al. 1999; Jeltsch et al. 1999; Wiegand and Moloney 2004). In accordance with this approach, analysis of spatial patterns in rangelands is used to infer the existence of underlying processes, which may operate at different spatial scales in the paddock. However, the number of studies that apply such techniques is still low in rangeland ecology (Adler et al. 2001).

The assessment of the impact of grazing on soil erosion processes prevailing in arid rangelands requires the selection of adequate indicators, or relevant process-related parameters to quantify them. Blowouts have been indicated as the most common aeolian erosional landforms in dune landscapes in arid zones (Hesp and Hyde 1996). Blowouts are depressions or hollows formed by wind erosion on a preexisting sand deposit (Hesp 2002) and are common features in vegetation-stabilized dune fields (Livingstone and Warren 1996). Vegetated parabolic dunes are leeward extensions of blowouts. Plants colonize, and may eventually stabilize, the trailing arms, which are formed by the advancing dune apex (Melton 1940; Verstappen 1968; Pye 1982; Eriksson et al. 1989). Grazing, however, can contribute to destabilization of dunes (e.g., de Stoppelaire et al. 2004). The vegetated dune field at Península Valdés (northeastern coast of Patagonia) is a good system to deal with spatial patterns of soil erosion processes. Dunes were formed in the upper Pleistocene from loose, sand-sized sediment of the sandy beaches and cliffs exposed to the prevalent westerly winds (Beltramone et al. 1990). Nowadays, dunes are mostly stabilized and the presence of blowouts is the best evidence of erosive processes in the dune field (Súnico 1996).

The emphasis of this paper is on the analysis of the changes induced by grazing on soil erosion processes prevailing in a vegetated dune field at Península Valdés, using the spatial pattern of blowouts as an indicator of erosion intensity. We used distance-dependent spatial statistics to identify scales at which the spatial pattern of blowouts was significantly aggregated around water points (i.e., "critical scales"). We hypothesized that large numbers of livestock concentrated at water points may destroy vegetation cover, resulting in dune reactivation and consequently generating blowouts. Accordingly, we expected that the impact of livestock on soil erosion processes was greatest in sites near water points relative to those farther from water points (i.e., a utilization gradient). This gradient should result in aggregation of blowouts near water holes. However, the spatial structure of the sites sensitive to erosion (i.e., dune crests) may confound a direct effect. We therefore analyzed blowout densities at different distances away from water points to see if they were higher than expected by a random distribution of blowouts over the dune crest (i.e., after removing potential spatial structures). Besides, the critical scale of aggregation should increase under grazing. Considering that vegetation cover varies with position on the dune, we also analyzed the effects of the spatial distribution of dune crests around water points on the spatial pattern of blowouts. We hypothesized that the effect of livestock on soil erosion processes is influenced by the preexisting spatial pattern of dune crests. Thus, we expected that the grazing disturbance was greatest in sites with a higher density of dune crests.

\section{METHODS}

\section{Study Site Description}

The dune field is located in the southern portion of the Península Valdés (lat $42^{\circ} 32^{\prime} \mathrm{S}$, long $63^{\circ} 54^{\prime} \mathrm{W}$ ) in the northeastern region of Patagonia, southern Argentina. The climate is semiarid, characterized by an annual mean temperature of $13^{\circ} \mathrm{C}$ and an average annual rainfall (1912-2002) of $231 \mathrm{~mm}$, with high mean interannual variation (coefficient of variation $=30 \%$; Barros and Rivero 1982). The prevailing winds are from the west and northwest (Coronato 1994). Mean annual wind speed is $25 \mathrm{~km} \cdot \mathrm{h}^{-1}$ (Barros et al. 1981). It is highly influenced by intense winds from the northeast prevailing from October to February (Labraga 1994). Sheep were introduced in the area at the beginning of last century (Defossé et al. 1992) and are presently raised in large estancias (10000 ha or more), usually consisting in several paddocks around a shared water point.

The source of sediment for the dune field are the sandy beaches of Nuevo Gulf where a continued supply of loose, sand-sized sediment is available to be transported inland by the prevailing westerly winds (Haller et al. 2000). General features 
in the topography of the dune field are relic aeolian landforms, megapatches of active sand dunes, and erosional features such as blowouts and deflation plains. Relict aeolian landforms would have been formed in a periglacial environment (Iriondo and García 1993; Trombotto 1998), and include sand sheets and linear dunes stabilized by psammophile species such as Sporobolus rigens and Hyalis argentea (Bertiller et al. 1981). Megapatches of active sand dunes include a series of aeolian forms as barchan, dome, and transverse dunes. The currently visible wind shaping of these dunes has been active since the upper Pleistocene (Beltramone et al. 1990).

Sizes and shapes of blowouts on the dune field at Península Valdés vary considerably. Blowouts have lengths varying from just a few meters to more than $100 \mathrm{~m}$, and morphologies that range from circular hollows to elongated corridors. Some of them are associated with parabolic dunes. Blanco (2004) measured the migration rates of 15 parabolic dunes for the period 1969-2002. The average distance traveled by parabolic dunes in the dune field between 1969 and 2002 was $334 \mathrm{~m}$, equivalent to an average migration rate of $10.1 \mathrm{~m} \cdot \mathrm{yr}^{-1}$. From the calculated migration rates and measured distance between the origin of blowouts and the edge of the deflation plain in 1969 , it can be calculated how many years it would take the blowouts to reach this length. The maximum and lowest ages for blowouts associated with parabolic dunes were estimated at 71 and 32 yr (Blanco 2004).

\section{Grazing Rates}

We studied paddocks in which the stocking rate and the location of fences and water had remained fairly unchanged for at least the last four decades. Therefore, the present study was limited to eight paddocks (covering a total of about $6600 \mathrm{ha}$ ) under two sheep grazing intensities: four paddocks were lightly grazed and four heavily grazed. We calculated that lightly grazed paddocks had a stocking rate ca. 0.4 sheep $\cdot \mathrm{ha}^{-1}$ and heavily grazed paddocks ca. 0.8 sheep $\cdot \mathrm{ha}^{-1}$. Each of the paddocks had one single water point. The maximum distance in each paddock from the water point ranged between 1.9 and $4.6 \mathrm{~km}$.

\section{Mapping Blowouts, Dune Crests, and Water Points}

Blowouts and dune crests were identified using historical aerial photographs, taken in January 1969 by the Instituto Geográfico Militar. For a current perspective of these aeolian features we used a Landsat 7 Enhanced Thematic Mapper Plus image from 10 October 2002 with a spatial resolution of $30 \mathrm{~m}$ and with a minimum mapping unit of $9 \times 10^{-2}$ ha. Aerial photographs were scanned at a resolution of 600 dots per inch and converted to tagged interchange format (TIFF) for use in Erdas Imagine software (Erdas Inc. 2003). These images were georeferenced and projected into a Transverse Mercator projection with WGS 1984 spheroid and datum. The maximum error between the transformation model and the reference coordinates was less than one pixel. The maps were scaled at 1:60000, with a pixel resolution of $6 \mathrm{~m}$ and a minimum mapping unit of $0.36 \times 10^{-2}$ ha. The georeferenced aerial photos were joined together to form a single rectified mosaic.

We mapped the polygons of erosional features (blowouts and deflation plains) on the mosaic of aerial photos. Point maps were then made for each paddock in order to represent the positions of origins of blowouts and deflation plains. Also, the crests of stabilized linear dunes were mapped and arc maps were obtained. Furthermore, we generated point maps of water point locations. All maps were exported as shapefiles.

Aerial photos were used to geometrically correct, coregister, and project the Landsat image. Stable points, such as cultural landmarks that could be located on the images, were used to coregister and rectify the imagery. A root mean square error of less than one pixel was obtained. The image was then classified using a supervised classification scheme with a maximum likelihood classifier (Erdas Inc. 2003). Three classes were defined: 1) blowouts and deflation plains, 2) active sand dunes, and 3) vegetated areas. Ground-truth data were obtained in summer 2003 to determine the classification accuracy. Raster blowouts and deflation plains were vectorized as polygons and then we built point maps representing them for each paddock. These maps were exported as shapefiles.

The geographical information systems software ArcView 3.3 (ESRI 2002) was used to transform shapefile data into a rasterized Arc/Info grid format, with a resolution of $30 \times 30 \mathrm{~m}$. For each paddock, a map was generated from the addition of grids of blowouts, dune crests, and water points (Fig. 1). The resulting maps were exported in ASCII 3 format.

\section{Analyzing Blowout Spatial Patterns}

Blowouts spatial patterns were analyzed with the O-ring statistic (Wiegand et al. 1999) using the Programita software (Wiegand and Moloney 2004). The bivariate O-ring statistic $\mathrm{O}_{12}(r)$ describes the spatial relationship between two types of points (type 1 points and type 2 points) as function of distance $r$, summarizing the information on the distances between all pairs of type 1-type 2 points. More formally, the bivariate $\mathrm{O}$ ring statistic $\mathrm{O}_{12}(r)$ can be defined as the density of type 2 points in a ring with width $w$ at distance $r$ from an arbitrary type 1 point (Wiegand and Moloney 2004). Note that the $\mathrm{O}_{12}(r)$ is related to the derivative of Ripley's $K$ function (Ripley 1981), i.e., $O_{12}(r)=\lambda_{2} K_{12}{ }^{\prime}(r) /(2 \pi r)$ where $\lambda_{2}$ is the intensity of the pattern of type 2 points in the study area (Wiegand and Moloney 2004). The main difference between $\mathrm{O}_{12}$ and $K_{12}$ is that the $K$ function is an accumulative statistic and $\mathrm{O}_{12}$ is noncumulative. Therefore, the spatial pattern at small scales does not directly influence the $O$ statistic at larger scales, whereas the cumulative $K$ function confounds effects at larger distances with effects at shorter distances (Getis and Franklin 1987). The present study requires using a noncumulative statistic because we search for critical scales in the spatial patterns of blowouts along utilization gradients by livestock.

We used a grid-based estimator of the O-ring statistic such as that used by Wiegand et al. (1999) and Condit et al. (2000) and explained in detail by Wiegand and Moloney (2004). The spatial resolution was in accordance to our raster data, $30 \times 30 \mathrm{~m}$, and we used a ring width of $w=150 \mathrm{~m}$ to avoid jagged plots of $\mathrm{O}_{12}$ (which result if not enough blowouts fall within the rings). In our study the type 1 points were water points and the type 2 points were blowouts. We analyzed the area covered by the lightly grazed paddocks and that covered by the heavily grazed paddocks separately.

In a first step we calculated for each paddock $i$, the number of blowouts in rings with fixed width $w=150 \mathrm{~m}$ and variable 


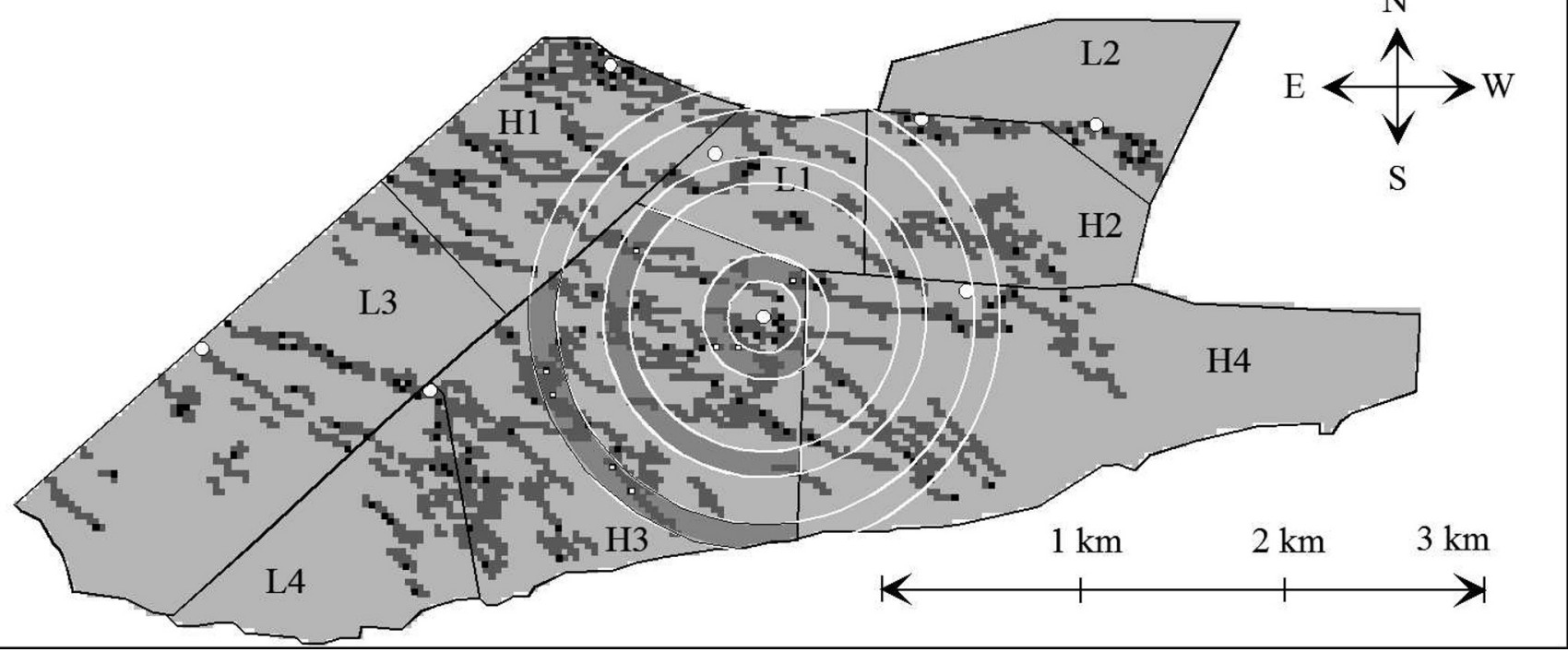

Figure 1. Study area and example for the calculation of the 0 -ring statistics in paddock H3. The irregularly shaped study area is represented by a light grey color, dune crests are represented as dark grey, blowouts are shown as black squares, and water points are shown as white disks. The four lightly grazed paddocks are labeled as L1, L2, L3, and L4, and the four heavily grazed paddocks are labeled as $\mathrm{H} 1, \mathrm{H} 2$, $\mathrm{H} 3$, and $\mathrm{H} 4$. For the calculation of the spatial statistics, rings with width $w=150 \mathrm{~m}$ and variable radius, $r$, are centered in the water hole of paddock $i$ and the number of blowouts (white squares; $=p_{\mathrm{i} 2}[r]$ ) and the number of cells with dune crests (dark grey; $=a_{\mathrm{i}}[\mathrm{r}]$ ) in the segment of the circles that fall inside the paddock are counted.

radius $r$ centered at the corresponding water point $\left(=p_{\mathrm{i} 2}[r]\right)$ and the area of dune crest within these rings $\left(=a_{\mathrm{i}}[r]\right.$; Fig. 1$)$. Note that blowouts and dune crests in the part of the rings outside the respective paddock do not count here (Fig. 1) because livestock could not move from one paddock to the other (e.g., livestock located at paddock H1 did not contribute to formation of the utilization gradient of paddock H2). In a second step we averaged over all four paddocks with the same treatment to obtain the estimator of the O-ring statistic:

$$
\hat{O}_{12}(r)=\frac{(1 / 4) \sum_{i=1}^{4} p_{i 2}(r)}{(1 / 4) \sum_{i=1}^{4} a_{i}(r)}
$$

To explore local effects within an individual paddock $i$ we also calculated the individual O-ring statistic:

$$
\hat{O}_{12}^{i}(r)=\frac{p_{i 2}(r)}{a_{i}(r)}
$$

To find out if and at which spatial scale blowouts were significantly aggregated around water holes we contrasted the empirical O-ring statistic to simulation envelopes constructed from Monte Carlo simulations of a null model that randomized the locations of the blowouts over the area of dune crests, thereby removing potential spatial correlation between water points and blowouts. Because water points preceded blowouts, the interaction can occur in only one direction; thus we kept the locations of the water holes unchanged.
The approximate $95 \%$ simulation envelopes were the 25 th lowest and highest value of $\mathrm{O}_{12}(r)$, taken from the 999 simulations of the null model. At a given distance $r$, a value of $\mathrm{O}_{12}(r)$ below or above the simulation envelop is interpreted as significant attraction or repulsion, respectively. However, the simulation envelopes cannot be interpreted as confidence intervals in a strict sense. Because of simultaneous inference (i.e., we tested all spatial scales $r$ simultaneously), type I error may occur if the value of $\mathrm{O}_{12}(r)$ is close to a simulation envelope (i.e., the null model may be rejected even if it is true; Loosmore and Ford 2006). However, although this is a special concern with the accumulative $K$ function, it is less a concern with noncumulative statistics (Loosmore and Ford 2006). Therefore, we interpret our results, especially small departures from the null model, with caution.

To find out if the density of dune crests around water points influences the soil erosion processes, we estimated the intensity of dune crests using a circular moving-window estimate with bandwidth of $R=60 \mathrm{~m}$ (Bailey and Gatrell 1995). The intensity of dune crests at a given location was given by the number of points that are located within a neighborhood with radius $R=60 \mathrm{~m}$, divided by the area of this neighborhood. If a neighborhood was partly outside the irregularly shaped study region, the number of points in the incomplete neighborhoods was divided by the proportion of the area that lay within the study region. We then classified the intensity of dune crests (measured in dune crests $\cdot 30 \times 30 \mathrm{~m} \mathrm{cells}{ }^{-1}$ ) roughly into low (intensity $<0.1$ ), medium (intensity $<0.6$ ), and high (intensity $>0.6$ ). Water points were classified according to their location into low, medium, and high dune crest-density water points. The densities of blowouts in the 300-m neighborhood of these three types of water points (given by the O-ring statistic) were compared by analysis of variance, for both lightly and heavily grazed paddocks. 

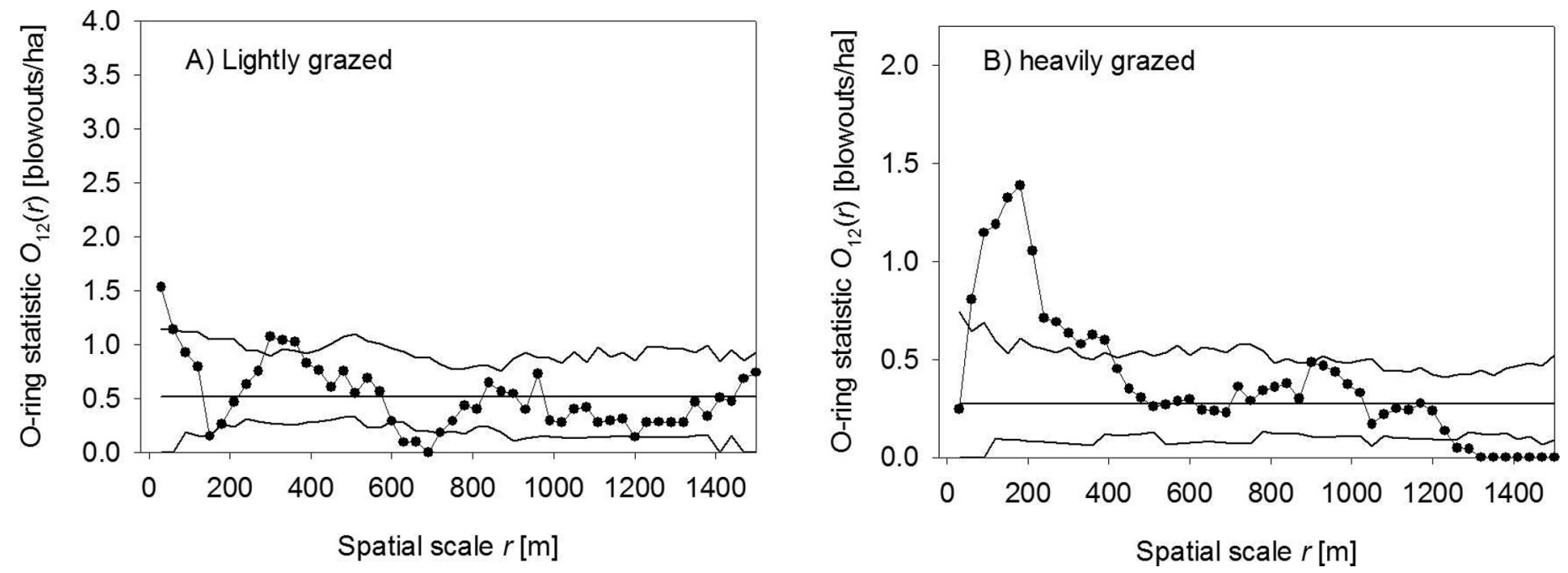

Figure 2. Blowout spatial patterns around water points under two grazing conditions: A, lightly grazed and $\mathbf{B}$, heavily grazed. $\bullet=$ ring statistic (blowouts $\cdot$ ha $^{-1}$ ); black lines indicate the upper and lower limits of the 95\% simulation envelope of the null model. Points above the envelope indicate aggregation and points below the envelope indicate regulate pattern. The horizontal lines indicate the overall density of blowouts.

\section{RESULTS}

A total of 171 blowouts were identified for the study area. On the mosaic of aerial photos (year 1969) 157 blowouts were digitized, but 14 new blowouts were identified on the Landsat image (year 2002). The area occupied by smaller blowouts on the mosaic and on the image corresponded with the minimum mapping unit for each sensor $\left(0.36 \times 10^{-2}\right.$ ha and $9 \times 10^{-2}$ ha, respectively). Therefore, blowouts generated after the year 1969 with areas smaller to $9 \times 10^{-2}$ ha could not be mapped.

The lightly grazed paddocks contained 63 blowouts and the heavily grazed paddocks, 108 (Fig. 1). The overall density of blowouts within dune crest areas was 0.52 and 0.28 blowouts $\cdot \mathrm{ha}^{-1}$ at the lightly and heavily grazed paddocks, respectively (gray horizontals lines in Fig. 2). Point-pattern analysis using the O-ring statistic reveals that blowouts at the lightly grazed paddocks showed weak small-scale aggregation (up to $30 \mathrm{~m}$ ) around water points and at distances of about $300 \mathrm{~m}$ from the water point (Fig. 2A). In contrast, in heavily grazed paddocks the aggregation of blowouts was strong at distances between 90 and $210 \mathrm{~m}$ from water points and significant at distances of $60-390 \mathrm{~m}$. Blowout density peaked at a distance of $180 \mathrm{~m}$, showing a density threefold higher than expected at random (i.e., the horizontal line in Fig. 2). In lightly grazed paddocks the aggregation was much weaker. Interestingly, density of blowouts did not peak at the heavily grazed paddock close to the water point, but some $200 \mathrm{~m}$ away. This result shows that the activity of livestock may have the strongest impact not immediately close to the water hole but a "walking distance" away.

To explore our data in more detail and to evaluate possible site effects, we also analyzed the data from each paddock separately using the individual O-ring statistics (equation 2). Clearly, because of the low sample sizes, stochastic effects were large. Nevertheless, we found in all four heavily grazed paddocks significant aggregation of blowouts at some distances from water points shorter than $400 \mathrm{~m}$ (Appendix, Fig. A1). In contrast, only one lightly grazed paddock showed aggregation of blowouts at distances shorter than $100 \mathrm{~m}$ (Appendix, Fig. $\mathrm{A} 2$, panel $\mathrm{D}$ ). The density of dune crests in relation to water point locations is shown in Figure 3. In two paddocks (H1 and L4), water points were located in areas with high density of dune crests, whereas in paddocks $\mathrm{H} 4$ and L1 water points were in areas with very low density of crests. In the remaining four paddocks, the water points were in areas with medium intensity of dune crests. To find out if the density of blowouts differed among water holes with low, intermediate, and high densities of dune crest we conducted two analyses of variance, separately, for lightly and heavily grazed paddocks. As measure of the density of blowouts we used the first 10 distance classes of the corresponding individual O-ring statistics. In lightly grazed paddocks blowout density increased systematically with density of dune crests, but we found a significant difference only between high density of dune crests and the low and intermediate class (Fig. 4A). In heavily grazed paddocks blowout density also increased systematically with density of dune crests, but we found a significant difference between low density of dune crests and the intermediate and high class (Fig. 4B). Thus, under light grazing, blowout density increased significantly only if water points were located in areas with a high density of dune crests, whereas blowout density significantly increased in heavily grazed paddocks if water points were located in areas with an intermediate density of dune crests.

\section{DISCUSSION}

By applying spatial analysis to data derived from remotely sensed imagery, detailed spatial information can be inferred when trying to understand the dynamic of soil erosion processes within desert rangelands. Furthermore, the indicator that we used, presence or absence of blowouts, is suitable for dealing with soil erosion processes, because blowouts reflect a 


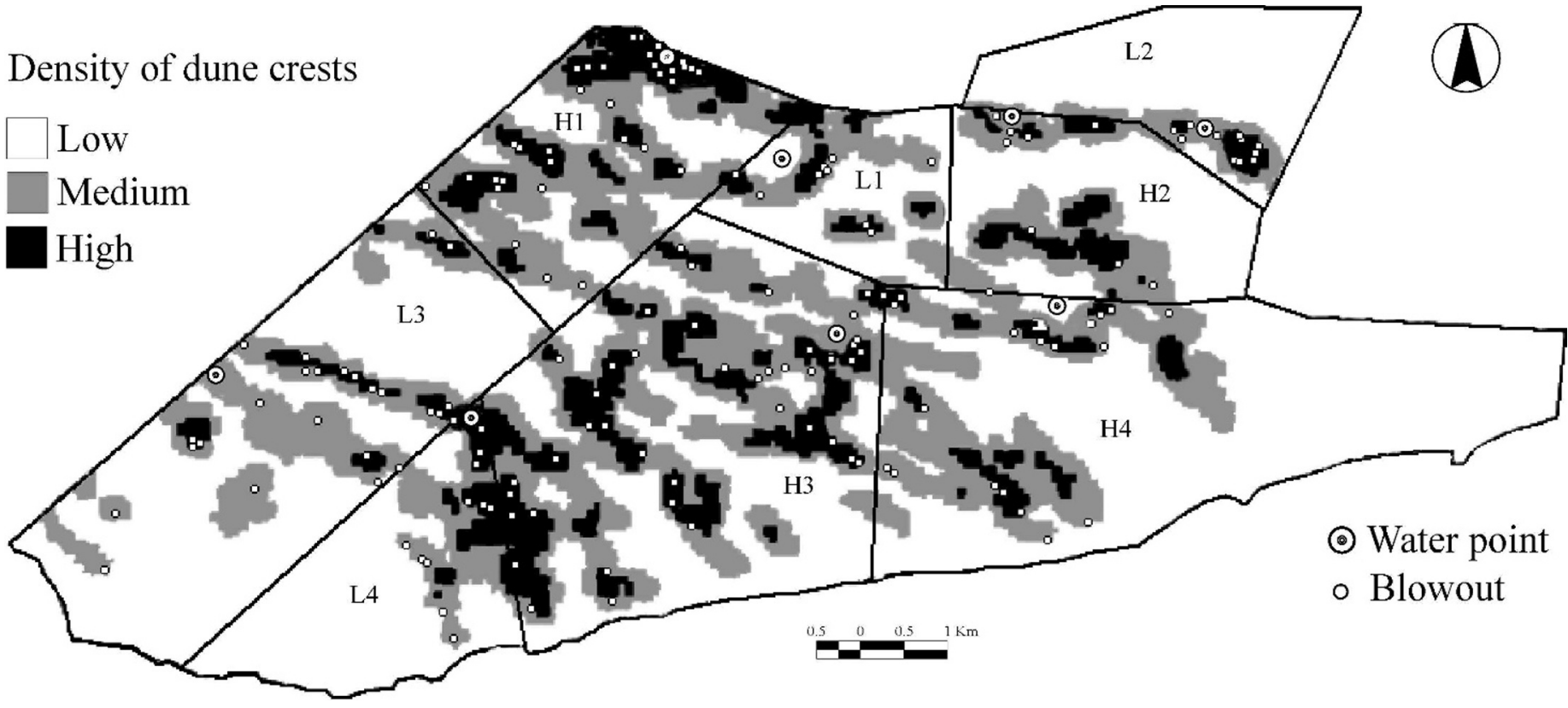

Figure 3. Density of dune crests and points representing blowouts and water points. H1-H4: paddocks heavily grazed; L1-L4: paddocks lightly grazed.

large temporal scale and also are quickly and easily detected in remote sensing images.

We found aggregated patterns of blowouts around water points in the vegetated dune field at Península Valdés, with significant aggregation under heavy grazing pressure. Under these conditions, sheep may severely affect soil stability through forage intake, trampling, and/or concentration in resting points (Evans 1998). Resting, which may at first glance represents a nondestructive, low-impact activity, can affect vegetation and soil stability if resting places are located in fragile sites (Evans 1997). Indeed, some of the blowouts found in the study area seem to have originated in resting places (bare areas with a high density of sheep feces). This may weaken our findings; however, the overall signature of aggregation of blowouts in the neighborhood of water points was strong enough to be significant. Other animals commonly mentioned as initiators of sandy soil surface erosion are rabbits (Ranwell 1960; Jungerius and Van der Meulen 1988), cows (Thom et al. 1992), bears (Martini 1981), and horses (Lucas 1988).

The aggregated pattern of blowouts around water points was stronger and occurred at larger distances under heavy sheep grazing compared with light sheep grazing. Strong aggregation occurred for heavily grazed paddocks between 90 and $210 \mathrm{~m}$. The absence of an aggregated pattern of blowouts close to the water point (less than $100 \mathrm{~m}$ ) could be because of the nature of piospheres. This innermost zone is usually trampled to dust because of heavy grazing disturbance (Trash and Derry 1999). Similar aggregation of blowouts around water points was found in other desert rangelands grazed by sheep (Nechaeva 1979). This author found an aggregated pattern of blowouts around water points at a larger distance (maximum of $3500 \mathrm{~m}$ ) in Central Asia sand rangelands. Grazing based in transhumance in Russian rangelands, which implies radius of sheep migration of about 5000 to $6000 \mathrm{~m}$ (Mainguet 1991), could explain the longer distance of the grazing effect.
In the established paddocks of Patagonia the animals graze at distances up to $3000 \mathrm{~m}$ from water points (Bisigato and Bertiller 1997).

Our results also suggest that responses of soil erosion processes to grazing impact contrast among sites with different sensitivity to accelerated erosion. As the availability of vulnerable sites to erosion increased (high density of dune crests around water points), grazing impacts on rangeland became more intense irrespective of the historical stocking rate. However, at a medium density of dune crests, the effects of grazing on blowout formation were only significant in the heavily grazed paddocks (Fig. 4). Increases of susceptibility to soil erosion in zones with a high density of dune crests may be explained by the topographic conditions (heights and depressions) where aerodynamic flows are laterally and horizontally compressed and accelerated, especially on the top of the dunes (Carter 1988). The approach taken here could even be
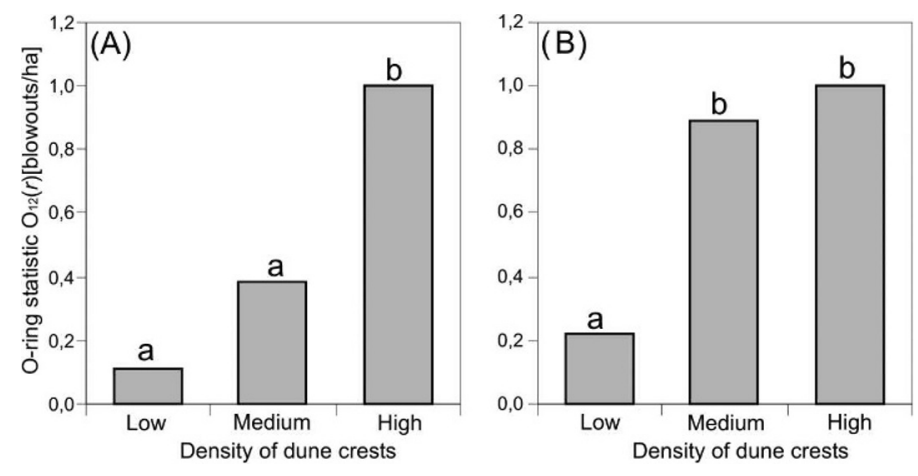

Figure 4. 0-ring statistic (blowouts $\cdot \mathrm{ha}^{-1}$ ) at distances from water point between 0 to $300 \mathrm{~m}$ - for low, medium, and high densities of dune crests-to $\mathbf{A}$, lightly grazed paddocks and $\mathbf{B}$, heavily grazed paddocks. Different letters indicate significant $(P>0.05)$ differences among spatial distribution of blowouts. 
extended to map the susceptibility of soil erosion in a qualitative way, based on the three variables of grazing regime, distance from water point, and dune crest density.

\section{MANAGEMENT IMPLICATIONS}

We found that grazing effects on soil erosion processes in the vegetated dune field at Península Valdés is conditioned by the spatial heterogeneity of sensitive sites to dune reactivation. Our findings suggest that the location of water points in sites less susceptible to suffering accelerated soil erosion should significantly improve with strategies based on reductions in stock. Sensitive areas can be fenced off to exclude livestock. Choices of fencing types could include sand fencing, which has an added component of facilitating the filling in of gaps in dune crests (Nordstrom 2000). Sand fences reduce wind speed near the ground, thereby causing moving sand to be deposited into a mound on the downwind side of the fence and reducing deposition farther downwind (Gares 1990). Our conclusion has significant management implications in desert rangelands, where the proposed management solutions have usually focused on the need to reduce the total number of livestock grazing.

\section{ACKNOWLEDGMENTS}

We wish to acknowledge the valuable suggestions made by Matthew Bowker and three anonymous reviewers. Also, Diego Giberto provided valuable suggestions that greatly improved the manuscript. As well, we are grateful to Fernando Coronato and Graciela Metternicht, who revised the English. Comisión Nacional de Actividades Espaciales from Argentina supplied the satellite images.

\section{LITERATURE CITED}

Adler, P. B., D. A. Raff, and W. K. Lauenroth. 2001. The effect of grazing on the spatial heterogeneity of vegetation. Oecologia 128:465-479.

Andrew, M. H., and R. T. Lange. 1986. Development of a new piosphere in arid chenopod shrubland grazed by sheep. 1. Changes to the soil surface. Australian Journal of Ecology 11:395-409.

Bailey, T. C., and A. C. Gatrell. 1995. Interactive spatial data analysis. Essex, UK: Longman Scientific and Technical. $413 p$.

Barot, S., J. Gignoux, and J. C. Menaut. 1999. Demography of a savanna palm tree: predictions from comprehensive spatial pattern analyses. Ecology 80:1987-2005.

Barros, V. R., and M. Rivero. 1982. Mapas de probabilidad de la precipitación en la Provincia de Chubut. Contribución 54. Puerto Madryn, Argentina: CENPATCONICET. $25 \mathrm{p}$.

Barros, V. R., M. Rivero, J. A. Rodriguez Seró, and J. C. Labraga. 1981. Primeras Jornadas de Energía Eólica. Contribución 56. Puerto Madryn, Argentina: CENPAT-CONICET. $102 \mathrm{p}$.

Bastin, G. N, G. Pickup, V. H. Chewings, and G. Pearce. 1993. Land degradation assessment in central Australia using a grazing gradient method. Rangeland Journal 15:190-216.

Beltramone, C., M. Villegas, and A. Demichelis. 1990. Depósitos eólicos del sur de Península Valdés, Chubut. In: Proceedings of III Reunión Argentina de Sedimentología; 20-24 May 1990; San Juan, Argentina. La Plata, Buenos Aires, Argentina: Asociación Argentina de Sedimentología. p. 360-365.

Bertiller, M. B., A. M. Beeskow, M. Del, and P. Irisarri. 1981. Caracteres fisonómicos y florísticos de vegetación del Chubut: La Península Valdés y el
Istmo Ameghino. Contribución 41. Puerto Madryn, Argentina: CENPATCONICET. $20 \mathrm{p}$.

Bisigato, A. J., and M. B. Bertlller. 1997. Grazing effects on patchy dryland vegetation in northern Patagonia. Journal of Arid Environments 36:639-653.

Blanco, P. D. 2004. Características morfológicas y dinámica de los focos de deflación de los pastizales naturales del suroeste de Península Valdés (Chubut) [thesis]. Puerto Madryn, Argentina: Facultad de Ciencias Biológicas, Universidad Nacional de la Patagonia San Juan Bosco. 87 p.

Carter, R. W. G. 1988. Coastal environments. London, UK: Academic Press. 617 p. Condit, R., P. S. Ashton, P. Baker, S. Bunyavejchewin, S. Gunatilleke, N. Gunatilleke, S. P. Hubbell, R. B. Foster, A. Itoh, J. V. Lafrankie, H. S. Lee, E. Losos, N. Manokaran, R. Sukumar, and T. Yamakura. 2000. Spatial patterns in the distribution of tropical tree species. Science 288:1414-1418.

Coronato, F. R. 1994. Clima del Nordeste del Chubut. In: A. Súnico, P. Bouza, C. Cano, H. del Valle, L. Videla, and A. Monti [EDs.]. Séptima Reunión de Campo del Comité Argentino para el Estudio del Cuaternario (CADINQUA). Puerto Madryn, Argentina: CENPAT-CONICET. p. 13-20.

Defossé, G. E., M. B. Bertiller, and C. M. Rostagno. 1992. Range management and development in Argentine Patagonia: past, present and perspectives for the future. In: G. K. Perrier and C. W. Gay [EDS.]. Proceedings of the International Rangeland Development Symposium; 11-12 February 1992; Spokane, WA, USA. Wheat Ridge, CO, USA: Society for Range Management. p. 12-21.

De Stoppelaire, G. H., T. W. Gillespie, J. C. Brock, and G. A. Tobin. 2004. Use of remote sensing techniques to determine the effects of grazing on vegetation cover and dune elevation at Assateague Island National seashore: impact of horses. Environmental Management 34:642-649.

ERDAS, Inc. [computer program]. 2003. ERDAS, version 8.7. Available at: http:// www.erdas.com/. Accessed 18 January 2008.

Eriksson, P. G., N. Nixon, C. P. Snyman, and J. du P. Bothma. 1989. Ellipsoidal parabolic dune patches in the Southern Kalahari Desert. Journal of Arid Environments 16:111-124.

ESRI [computer program]. 2002. ArcView, version 3.3. Available at: http:// www.esri.com/. Accessed 18 January 2008.

Evans, R. 1997. Soil erosion in the UK initiated by grazing animals. Applied Geography 17:127-141.

Evans, R. 1998. The erosional impacts of grazing animals. Progress in Physical Geography 22:251-268.

Gares, P. A. 1990. Eolian processes and dune changes at developed and undeveloped sites, Island Beach, New Jersey. In: K. F. Nordstrom, N. P. Psuty, and R. W. G. Carter [EDs.]. Coastal dunes: form and process. Chichester, United Kingdom: John Wiley \& Sons Ltd. p. 361-378.

Getis, A., and J. Franklin. 1987. Second-order neighborhood analysis of mapped point patterns. Ecology 68:474-477.

HAase, P. 1995. Spatial pattern analysis in ecology based on Ripley's K-function: introduction and methods of edge correction. Journal of Vegetation Science 6:572-582.

Haller, M. J., A. J. Monti, and C. M. Meister. 2000. Hoja Geológica 4363-I: Península Valdés, Provincia del Chubut. Programa Nacional de Cartas Geológicas de la República Argentina, 1:250000. Boletín 266. Buenos Aires, Argentina: Servicio Geológico Minero Argentino.

HeSP, P. A. 2002. Foredunes and blowouts: initiation, geomorphology and dynamics. Geomorphology 48:245-268.

Hesp, P. A., AND R. Hyde. 1996. Flow dynamics and geomorphology of a trough blowout. Sedimentology 43:505-525.

IRIondo, M. H., AND N. O. GarCiA. 1993. Climatic variations in the Argentine plains during the last 18000 years. Palaeogeography, Palaeoclimatology, Palaeoecology 101:209-220.

James, C. D., J. LAndsberg, and S. R. Morton. 1999. Provision of watering points in the Australian arid zone: a review of effects on biota. Journal of Arid Environments 41:87-121.

Jeltsch, F., S. J. Milton, and K. A. Moloney. 1999. Detecting process from snapshot pattern: lessons from tree spacing in the southern Kalahari. Oikos 85:451-467.

Jungerius, P. D., and F. Van Der Meulen. 1988. Erosion processes in a dune landscape along the Dutch coast. Catena 15:217-228. 
Labraga, J. C. 1994. On extreme winds in Pampa del Castillo Plateau, Patagonia Argentina, with reference to wind farm settlement. Journal of Applied Meteorology 33:85-95.

Lange, R. T. 1969. Grazing impact in relation to livestock watering points. Journal of Range Management 22:396-400.

Livingstone, I., and D. S. G. Thomas. 1993. Mode of linear dune activity and their palaeoenvironmental significance: an evaluation with reference to southern African examples. In: K. Pye [ED.]. The dynamics and context of aeolian sedimentary systems. London, United Kingdom: Geological Society. p. 91-101.

Livingstone, I., and A. Warren. 1996. Aeolian geomorphology: an introduction. Essex, United Kingdom: Longman. 221 p.

Loosmore, N. B., and E. D. Ford. 2006. Statistical inference using the $\mathrm{G}$ or $\mathrm{K}$ point pattern spatial statistics. Ecology 87:1925-1931.

LUCAS, Z. 1988. Vegetation and terrain management on Sable Island. Conservation 12:9-11.

LudWIG, J. A., J. A. Wiens, AND D. J. TongWay. 2000. A scaling rule for landscape patches and how it applies to conserving soil resources in savannas. Ecosystems 3:84-97.

Mainguet, M. 1991. Desertification. In: Natural background and human mismanagement. Berlin, Germany: Springer-Verlag. p. 108-110.

MaRTINI, I. P. 1981. Coastal dunes of Ontario: distribution and geomorphology. Geographie Physique et Quaternaire 35:219-229.

Melton, F. A. 1940. A tentative classification of sand dunes: its application to dune history in the southern High Plains. Journal of Geology 48:113174.

Nechaeva, N. T. 1979. Impact of pasture utilization regime on productivity of the Kara-Kum vegetation. Problemy Osvoenya Pustyn' 6:8-18.

Nordstrom, K. F. 2000. Beaches and dunes of developed coasts. Cambridge, United Kingdom: Cambridge University Press. 338 p.

[OIES] Office of Interdisciplinary Earth Studies. 1991. Arid ecosystem interactions. Boulder, CO: Office of Interdisciplinary Earth Studies. $81 \mathrm{p}$.

Pickup, G., G. N. Bastin, And V. H. CheWings. 1994. Remote-sensing-based condition assessment for nonequilibrium rangelands under large-scale commercial grazing. Ecological Application 4:497-517.

PYE, D. 1982. Morphological development of coastal dunes in a humid tropical environment, Cape Bedford and Cape Flattery, North Queensland. Geografiska Annaler 64(A):212-227.
Ranwel, D. S. 1960. Newborough Warren, Anglesey. III: changes in the vegetation on parts of the dune system after the loss of rabbits by myxamatosis. Journal of Ecology 48:385-395.

RIPLEY, B. D. 1981. Spatial statistics. New York, NY, USA: John Wiley \& Sons. 252 p.

Sparrow, A. D., M. H. Friedel, and D. J. Tongway. 2003. Degradation and recovery processes in arid grazing lands of central Australia. 3: Implications at landscape scale. Journal of Arid Environments 55:349-360.

Súnico, A. 1996. Geología del cuaternario y Ciencia del Suelo: relaciones geomórficas-estratigráficas con suelos y paleosuelos [PhD thesis]. Buenos Aires, Argentina: Facultad de Ciencias Exactas y Naturales, Universidad Nacional de Buenos Aires. $227 \mathrm{p}$.

Thom, B. G., M. J. Shepherd, C. Ly, P. Roy, G. M. Bowman, and P. A. Hesp. 1992. Coastal geomorphology and quaternary geology of the Port Stephens-Myall Lakes area. A.N.U. Monograph 6. Canberra, Australia: ANUTech Pty Ltd. 407 p.

TrASH, I., AND J. F. DeRRY. 1999. The nature and modelling of piospheres: a review. Koedoe 42:73-94.

Tromвotтo, D. 1998. Paleo-permafrost in Patagonia. Bamberger Geographische Schriften 15:133-148.

[UNEP] United Nations Environment Programme. 2006. Global deserts outlook. In: E. Ezcurra [ed.]. Nairobi, Kenya: Division of Early Warning and Assessment, United Nations Environment Programme. p. 100-102.

Valentine, K. A. 1947. Distance from water as a factor in grazing capacity of rangeland. Journal of Forestry 45:749-754.

Van Den Ancker, J. A. M., P. D. Jungerius, and L. R. Mur. 1985. The role of algae in the stabilization of coastal dune blowouts. Earth Surface Processes and Landforms 10:189-192.

VerstapPen, H. T. 1968. On the origin of Iongitudinal (seif) dunes. Zeitschrift für Geomorphologie NF 12:200-220.

Wasson, R. J., and P. M. Nanninga. 1986. Estimating wind transport of sand on vegetated surface. Earth Surface Processes and Landforms 11:505-514.

Wiegand, T., and K. A. Moloney. 2004. Rings, circles, and null models for point pattern analysis in ecology. Oikos 104:209-229.

Wiegand, T., K. A. Moloney, J. Naves, and F. Knauer. 1999. Finding the missing link between landscape structure and population dynamics: a spatially explicit perspective. American Naturalist 154:605-627.

Wiggs, G. F. S., D. S. G. Thomas, J. E. Bullard, and I. Livingstone. 1995. Dune mobility and vegetation cover in the southwest Kalahari Desert. Earth Surface Processes and Landforms 20:515-529.

Wolfe, S. A., And W. G. NickLIng. 1993. The protective role of sparse vegetation in wind erosion. Progress in Physical Geography 17:50-68. 

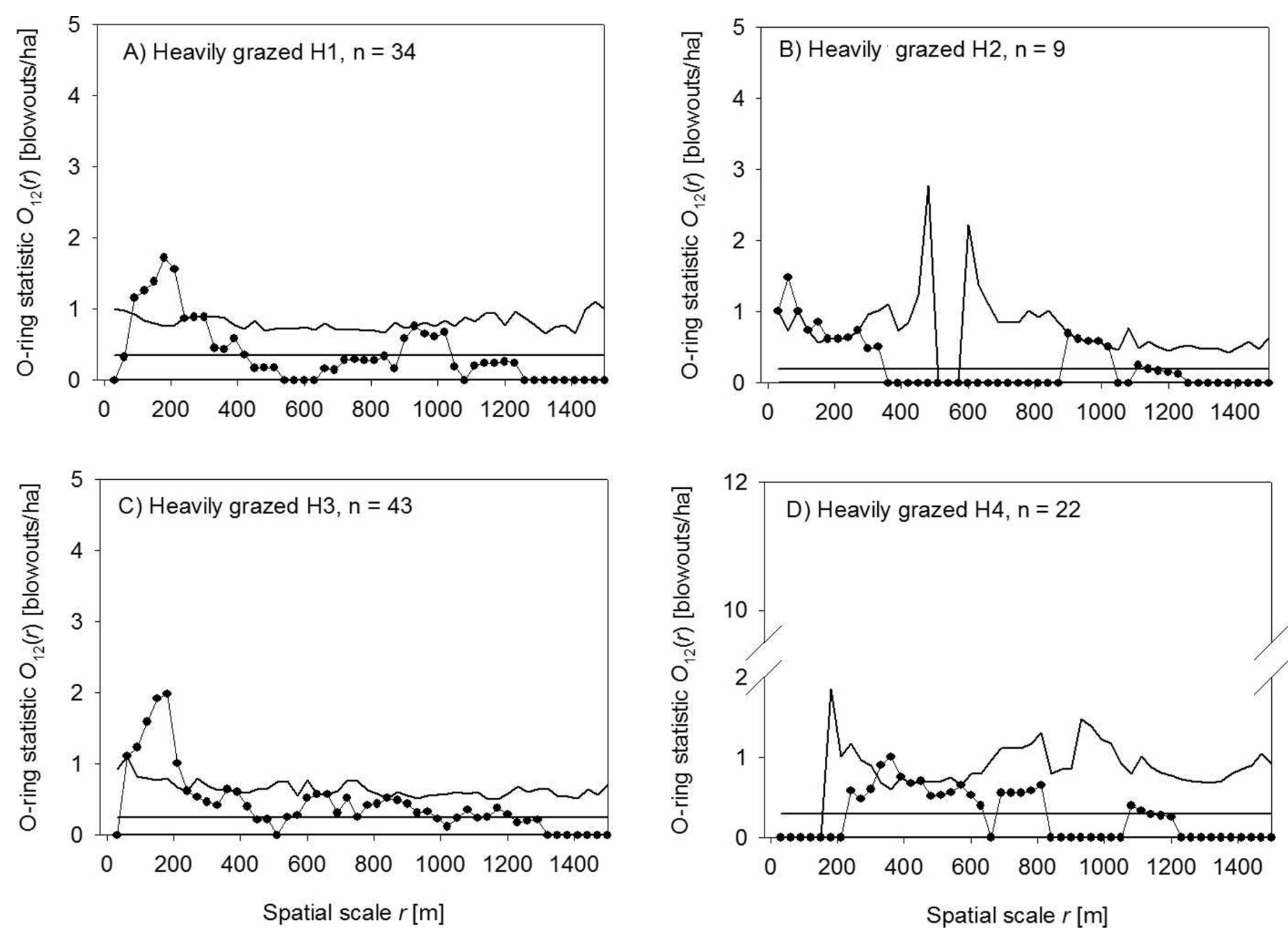

Figure A1. Blowout spatial pattern around water points in heavily grazed paddocks. $\bullet=$ ring statistic (blowouts $\cdot$ ha $^{-1}$ ); black lines indicate the upper and lower limits of the $95 \%$ simulation envelope of the null model. Points above the envelope indicate aggregation and points below the envelope indicate regulate pattern. The horizontal lines indicate the overall density of blowouts. 

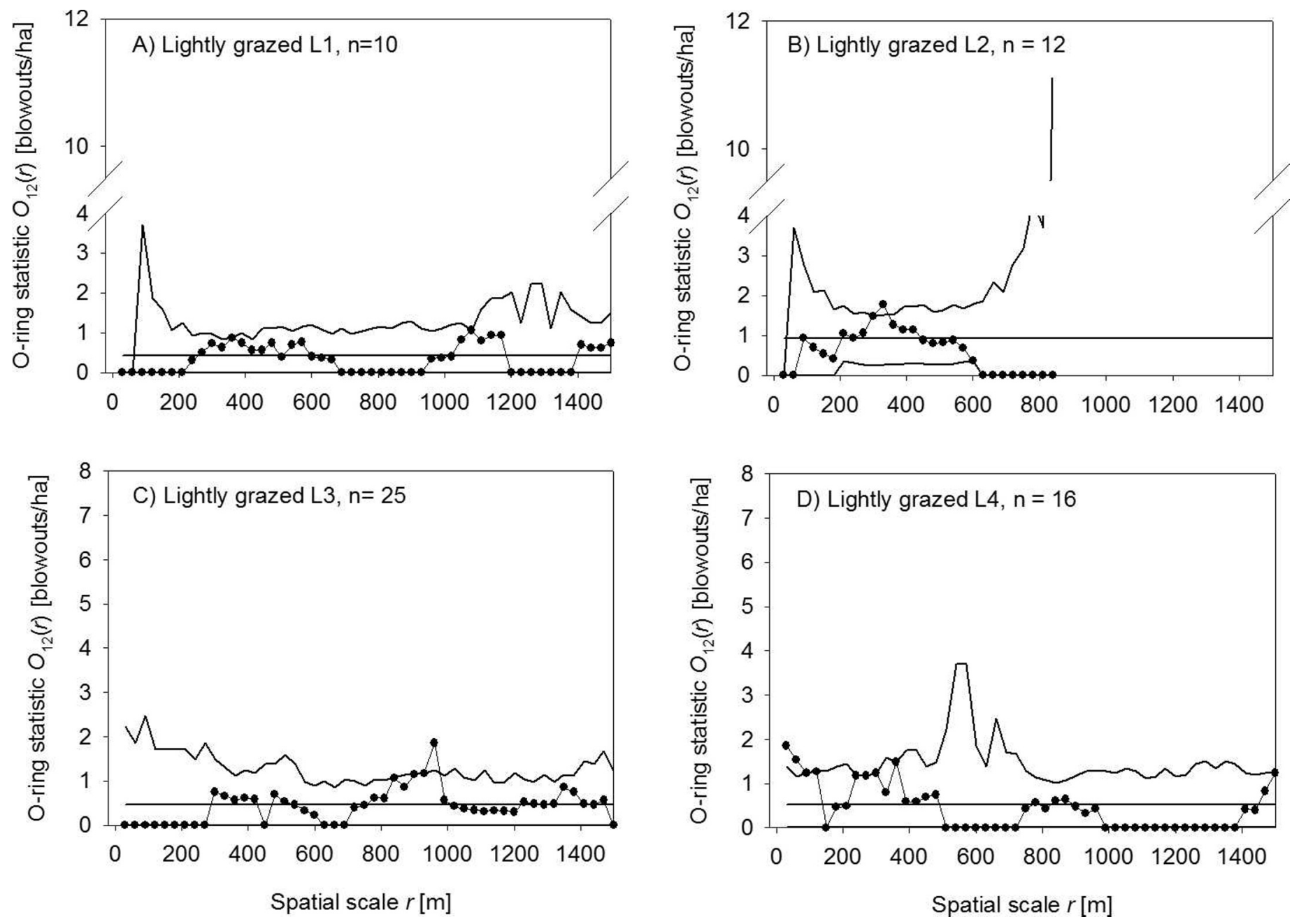

Figure A2. Blowout spatial pattern around water points in lightly grazed paddocks. $\bullet=$ ring statistic (blowouts $\cdot$ ha $^{-1}$ ); black lines indicate the upper and lower limits of the $95 \%$ simulation envelope of the null model. Points above the envelope indicate aggregation and points below the envelope indicate regulate pattern. The horizontal lines indicate the overall density of blowouts. 